\title{
Risks Faced by Islamic Banks: A Study on the Compliance Between Theory and Practice
}

\author{
Salma Rhanoui ${ }^{1} \&$ Khalid Belkhoutout ${ }^{1}$ \\ ${ }^{1}$ Faculty of Law, Economics and Social Sciences - Souissi, Mohammed V University, Rabat, Morocco \\ Correspondence: Salma Rhanoui, PhD Student, Faculty of Law, Economics and Social Sciences - Souissi, \\ Mohammed V University, Rabat, Morocco.
}

Received: March 30, 2019

Accepted: April 15, 2019

Online Published: April 22, 2019

doi:10.5430/ijfr.v10n2p137

URL: https://doi.org/10.5430/ijfr.v10n2p137

\begin{abstract}
Risk management is an active field where applications are reconsidered after each obstacle. Islamic banks are not excluded from this rule, particularly when they operate in a global financial system, in which they are occasionally forced to follow conventional banking rules. Nevertheless, Islamic banks are part of a less-advanced industry and face many challenges when handling risk. In theory, Islamic banks are confronted with two categories of risk: common risks, which are similar to the risks faced by conventional banks and risks specific to Islamic banks, due to their specificities and methods of operation. However, practice does not necessarily reflect this dichotomy. Therefore, the purpose of this paper is to make a compliance study between the theory and practice of Islamic banking risks. More precisely, it will compare all the risks fully recognized by the theory to the risks that are actually managed by the Islamic banks in their activities, using a sample of these institutions. The results of this qualitative approach, demonstrate that practice can be quite different from theory.
\end{abstract}

Keywords: compliance study, Islamic banks, practice, risks, theory.

\section{Introduction}

The banking industry rotates around risk. Banks are inclined to earn a profit by offering products that contort risk. Risk management of the banking system aims to minimize the effects and the potential for the occurrence of these risks (Yasin, 2014). Indeed, favorable management of banking risks has many advantages: banks that are armed with the knowledge of the risk exposure parameters should be able to more precisely assess the amount of resources to be allocated to prevention. This allows them to determine the form of reserves that are necessary to anticipate the risk. Plus, clients except a bank that is capable of managing its risks to be also able to provide optimal service and a better rate of return. The customer will trust this bank for the management of their funds.

Relatively new Islamic banks have coexisted or competed with the conventional banks that have always been present, which suggests that the management of Islamic banking risks is a pertinent topic.

The significance of risk management in banks has been highlighted in theory and practice. The Bank for International Settlements (BIS) has issued numerous publications on the importance of risk management in banks (Salem, 2013). The BIS has also defined guidelines to regulate banks and endorse their risk management procedures to promote a steady global environment. The Islamic Financial Services Board (IFSB) is among the supervisory organizations leading the industry towards a standardized regulatory framework and transparency.

Still, risk management in Islamic banks has not been sufficiently investigated for two reasons: the relatively recent nature of the industry compared to its conventional counterpart, and the rising market demand and attention paid to the Islamic banking industry. This has intensified research interest in this area (Ariss, 2010).

Since Islamic banking risk management is relatively recent, relevant research is scarce; most of the existing studies in this area have been limited to comparing the Islamic banking system and its conventional counterpart. No one has made a comparison between the stipulations of the theory and the reality of the practice within the Islamic banking system.

It is important to study this topic because if the leaders of Islamic banks are aware of the degree of compliance between theory and practice, they can more easily determine the tools and methods of managing their risks. This will allow Islamic banks to extend their businesses into riskier activities, creating higher profits and growth. Satisfactory 
risk management will ensure that risk-taking decisions match the bank's capacity for absorbing possible losses. Islamic banks must attain numerous risk management methods as risk precautions. This should be done from the very beginning: at the point of determining the risk management goals and plan. It is also necessary to identify, measure, and mitigate risks; ensure that there is running supervision; and report the implementation of risk management. Risk management practices must be continuous to match how risks repeatedly change and increase in amount and variety.

Thus, this study seeks to address the following research objectives:

a. To identify all the risks faced by Islamic banks in theory;

b. To use a sample of Islamic banks in Malaysia to determine whether practice conforms to theory regarding those risks;

c. To highlight the state of play in risk management within Islamic banks.

This paper is organized as follows: Section 2 provides a literature review. Section 3 highlights the theoretical panoply of risks faced by Islamic banks, while Section 4 focuses on the study's methodology and data. Section 5 presents and discusses the findings of this study. Section 6 concludes the paper.

\section{Literature Review}

This paper has two key terms: Islamic banking and risk.

\subsection{Islamic Banking}

\subsubsection{Definition}

Islamic banking has been defined in a number of ways all converge in their conformity to Shari'a (Islamic law) (Nwaolisa \& Kasie, 2013). For example, the Organization of Islamic Cooperation (OIC) has defined an Islamic bank as a financial institution whose statutes, rules and procedures expressly state its commitment to the principles of Shari'a. Ziauddin Ahmed (Note 1) has stated that Islamic bank is essentially a normative concept and can be defined as a bank whose conduct is in accordance with the values of Islam. The Institute of Islamic Banking and Insurance (IIBI) (Note 2) has contended that an Islamic bank refers to a banking system or activity that is in accordance with the principles of Shari'a and their application through the development of the Islamic economy.

The above definitions show that Islamic banking is a financial intermediation system that avoids the receipt and payment of interest in its transactions: it conducts its operations in a way that contributes to the objective of operating based on transactions where profit and loss sharing is a major feature, ensuring fairness and equity (Zeineb \& Mensi, 2014).

Furthermore, it should be noted that Islamic bankers do not expect to advance money and receive a predetermined amount on a fixed date in their transactions. Under Shari'a, they are instead responsible for ensuring that the money is invested in viable projects by reliable borrowers.

\subsubsection{Principles of Islamic Banking}

The five principles of the Islamic banking system consist of three prohibitions and two obligations, as follows:

- Prohibition of Riba: Riba, in Arabic, refers to excess, increase, addition, expansion or growth. Any interest or predetermined payment beyond the actual amount is prohibited by the Islamic bank (Guéranger, 2009). Riba is prohibited because it reinforces the tendency for wealth to accumulate in the hands of certain individuals (the lenders) to the detriment of others (the borrowers). In addition, Islam does not permit a gain in financial activity unless the beneficiary of this gain is also subject to the risk of potential loss. Finally, Islam considers the accumulation of wealth via interest or usury rather than hard work or physical efforts, as significantly harmful, which justifies its proscription. Siddiqi (2004) puts forward five reasons for the ban on Riba: (1) It would be unfair; (2) It would corrupt society; (3) It would imply a misappropriation of the property of others; (4) It would lead to negative growth; and, (5) It would degrade and diminish the human personality;

- Prohibition of Gharar and Maysir: Gharar usually translates to uncertainty. This definition implies that Gharar involves deception and is based on a lack of knowledge or a likelihood of delivery with the prospect of causing harm. Gharar continues to be one of the most difficult legal terms to understand. Perhaps the best way to appreciate its true significance is to cite some of its manifestations. These include ignorance of gender, species, attributes, object quantity or price; an inability to deliver or inspect the object; awarding a contract for a non-existent item; and the existence of several options in a contract unless one option is specifically chosen. Metwally (2006) argues that Gharar's tainted transactions are harmful to society. In the Islamic banking industry, the contracting 
parties must have perfect knowledge of the values to be exchanged in the transaction, and the contract terms must be well defined and unambiguous. The ban on Gharar is ultimately meant to prevent the exploitation of weakest borrowers.

Maysir means speculation. Ebrahim and Tan (2001) point out that Maysir introduces speculative elements into a contract to the extent that the expected gains are not clearly defined at the beginning of the transaction. Hameed (2009) defines Maysir as games and any form of commercial activity from which monetary gains are derived due to mere chance, speculation or conjecture. Finally, Iqbal and Molyneux (2005) contend that the ban on Masyir is justified because it is a game of chance, and any game inevitably creates financial problems. In addition, Maysir is completely useless for society since it brings no added value to the national economy;

- Prohibition of illicit investments or sectors: Shari'a prohibits the exercise of certain activities, and the Islamic banking system must ensure the strict application of this principle in its operations (Derbel, Bouraoui, \& Dammak, 2011). Thus, Islamic banks should only give their finances to tolerable and Shari'a compliant activities. This prevents the development of activities prohibited by Islam such as consuming alcohol and pork, and using armaments;

Profit and Loss Sharing (PLS): This contractual agreement is between a minimum of two parties and allows these parties to pool their resources in order to invest in a project (Ismayil, 2012). The parties then share the profits and losses based on their respective shares of the invested capital and their efforts with no guaranteed rate of return. By using this paradigm, it becomes possible to satisfy the financial needs of customers while respecting Islamic prescriptions. According to Khan (1986), the main advantage of PLS is that it leads to a more efficient allocation of capital, which depends on the productivity and viability of the project. Profit and loss sharing thus favors the creation of greater market discipline within Islamic banks;

- $\quad$ Asset-backing: This concept means that any transaction must necessarily be backed by a tangible asset such as a building (Derbel et al., 2011). Practices such as subprime mortgages or the opening of a simple line of credit cannot, therefore, be tolerated in an Islamic banking system.

\subsection{Risk}

\subsubsection{Definition}

Risk has been defined by Vaughan (1999) as a situation that involves the probability of deviation from the path that leads to the expected or usual result. Megginson (1997) has stated that, in simple terms, risk refers to the probability of loss (Elgari, 2003). The notion of risk should be distinguished from uncertainty: risk is the probability of the occurrence of an event where occurrence is uncertain. Just as certain events involve no risk, the same risk is generated by uncertainty.

For both Islamic and conventional banks, risks are uncertain future events that can influence the achievement of the bank's objectives, whether they are strategic, operational, financial or related to Shari'a compliance.

\subsubsection{Risk from the Islamic Perspective}

Ibn Taymiyya (Note 3) wrote that risk is divided into two categories from an Islamic point of view (Al-Suwailem, 2006):

- Commercial risk, whereby a good is bought for resale at a profit. This risk is acceptable for traders, because, occasionally selling at a loss is the nature of commerce;

- Gambling which involves unjust enrichment that is forbidden in Islam.

Thus, if we define risk as a mere possibility of loss, this risk would not be desirable from a purely Islamic point of view, because Shari'a clearly calls for the preservation and development of wealth. Exposing wealth to loss cannot be a purpose in itself.

This position is also held by Muslim scholars regarding the difficult actions of everyday life. According to Ibn Taymiyya, the reward for these actions is based on their utility rather than their difficulty. A good action may be difficult to achieve, but its goodness will overshadow that difficulty. The reward is all the more important because the difficulty involved is greater, and not because difficulty is the objective of the act, but rather because the act involves difficulty. In other words, the surrounding difficulties are secondary in determining the value of an act. Utility is the main factor.

This same reasoning can be applied to risk, which is considered to be a form of difficulty. Risk is not desirable as such, although it is intrinsic to virtually all economic activities. The value of an economic decision is not solely determined by the risks involved. It also includes consideration of, the created wealth and the added value of the 
choice.

The concern that arises here is how to distinguish between legitimate and forbidden risks in the Islamic approach. In this respect, Bouslama and Lahrichi (2017) have proposed a distinction between legitimate and prohibited risk. According to them, there are three main criteria that are usually used to determine whether the risk is acceptable: the degree of inevitability, the importance of the risk, and the degree to which it is intentional (Bouslama \& Lahrichi, 2017).

The first criterion of inevitability suggests that value cannot be created without the risk of loss: risk is inseparable from real transactions and value creation. In the Islamic context, separating risk from real transactions generates more risk and thus leads to greater instability in the economy. For example, conventional securitization involves trading debt for a specific price, which is forbidden.

The second criterion of importance concerns the degree of risk. According to Islamic thought, for risk to be acceptable, the possibility of failure must be lower than the likelihood of success. Therefore, gambling is forbidden in Islam because it is based on a solid possibility of losing.

The third criterion of intentionality concerns the other two criteria. The purpose of any economic activity is to generate value and not to create the risk that the activity introduces. This risk, therefore, cannot be planned as part of the transaction. An agent's decision should be driven by a purpose to thrive and to create value; the decision cannot be based on the strong possibility of losing. This rule makes it possible to distinguish between investment and gambling. The principal difference between the two is the probability of success: A businessperson starts a project because they believe it will succeed. A gambler knows in advance that they will probably lose, but the size of the prize to be won coaxes them to commit to a project that will probably not flourish. Therefore, an action that leads more often to failure than success cannot be considered to be a cause of success; it is a cause of failure.

In the light of these three criteria, every risk faced by Islamic banks is considered to be legitimate.

\section{Islamic Banking Risks in Theory}

In theory, Islamic banks are exposed to two types of risk: those faced by conventional banks and risks that are specific to Islamic banks. Figure 1 schematizes these risks and highlights the demarcations between the two.

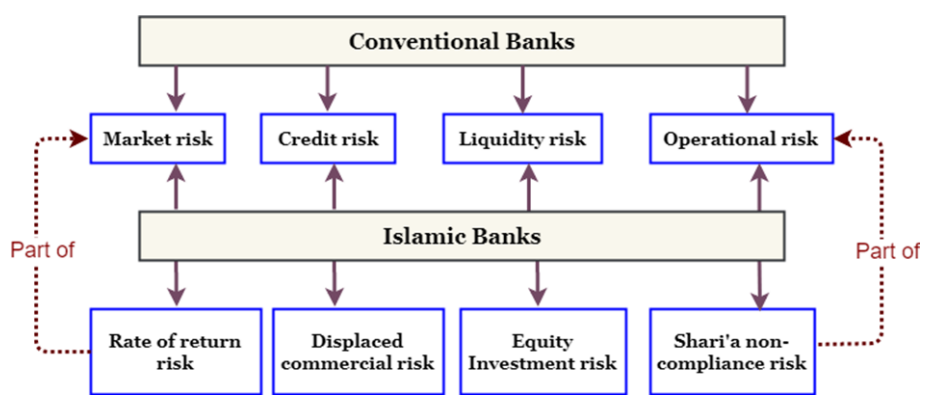

Figure 1. Risks faced by Islamic banks in theory

Source: Author

There are risks common to both conventional and Islamic banks, namely:

- Credit risk: The risk that a counterparty will not meet its obligations in accordance with the agreed upon terms (Helmy, 2012);

- Liquidity risk: The bank's potential loss resulting from its inability to fund an obligation on time without incurring unacceptable losses. This risk is also inherent in traditional intermediation activities. Overall, a bank that is unable to cope with massive and unexpected demand for cash withdrawals from its customers or other credit institutions is called illiquid (De Coussergués \& Bourdeaux, 2010);

- Market risk: This risk arises from an unfavorable change in the price of an asset that is generally traded on the market (De Coussergués \& Bourdeaux, 2010). Market risks include interest rate risk, foreign exchange rates risk, commodity price risk and equity price risk. These risks arise from the probability of loss as a result of the adverse movements of the following elements (Jouaber-Snoussi, 2012): 
- Interest rate risk: While this risk is fundamental in conventional banks, it plays a different role in Islamic banks. Since Islam prohibits interest, Islamic banking is theoretically excluded from exposure to this risk. In reality, the interest rate risk only takes a different form because, even if interest rate is not used by Islamic banks, they still use it as a reference for defining their margins. This practice is known as the rate of return risk, which is a risk that is specific to Islamic banks;

- $\quad$ Foreign exchange risk: This risk manifests itself when a portion of a bank's income or assets and liabilities are denominated in foreign currencies. All Islamic banking contracts, are potentially exposable to changes in exchange rates if denominated;

- Equity price risk: This risk concerns the market valuation of the bank's assets. A loss could be recorded by the bank if the value of its investments declines;

- Commodity price risk: This risk affects the value and financial flows of commodities.

- Operational risk: This risk is defined as the risk of loss resulting from inadequate or failed internal processes, people, systems or external events. This risk includes losses resulting from non-compliance with the Shari'a and failure to fulfill fiduciary responsibilities (Rhanoui \& Belkhoutout, 2018).

The IFSB, supplemented by contemporary doctrine, presents the possible operational risks for Islamic banks, as subsequently showed by Table 1 . These risks are in addition to the Shari'a non-compliance risk that is specific to Islamic banking.

Table 1. Operational risk aspects in Islamic banks excluding Shari'a non-compliance risk

\begin{tabular}{ll}
\hline Risk of external events & $\begin{array}{l}\text { Risk of loss caused by external incidents and other causes beyond the } \\
\text { control of the Islamic bank. }\end{array}$ \\
\hline People risk & $\begin{array}{l}\text { Risk generated by employees from intentional and unintentional events, that } \\
\text { can cause considerable damage to the Islamic bank. }\end{array}$ \\
\hline Technological risk & $\begin{array}{l}\text { Risk of the inability to track the advanced use of information technology } \\
\text { (IT) that could cause an Islamic bank to significantly lose in } \\
\text { competitiveness. }\end{array}$ \\
\hline Fiduciary risk & $\begin{array}{l}\text { Risk of loss arising from the Islamic bank's negligence, fault or violation of } \\
\text { their investment mandate. }\end{array}$ \\
\hline Legal risk & Risk of loss arising from legal matters. For instance, the Islamic bank or its \\
& employees might commit acts that violate the law and therefore result in \\
& sanctions to which the bank must submit. Another example is when the \\
Islamic bank is involved in a court case due to misinterpretation of then \\
laws and regulations in force.
\end{tabular}

Source: (Rhanoui \& Belkhoutout, 2018)

The risks specific to Islamic banks are as follows:

- Shari'a non-compliance risk: The risk that arises from failing to comply with Shari'a rules and principles as determined by the Shari'a board of the bank (Lahsasna, 2014);

- Rate of return risk: This risk is closely linked to the rate of return provided to investment account holders, who are also known as depositors in Islamic banks. These depositors will be disappointed if they receive, returns on their deposits that are lower than the market rate (Salem, 2013). The rate of return risk therefore corresponds with an adverse change in the investor's expectations regarding an investment's rate of return;

- Displaced commercial risk: This risk is a consequence of the rate of return risk in Islamic banks and manifests itself whenever the bank finds itself unable to pay competitive rates of return (Kasri, 2007). This result is likely to encourage depositors to withdraw their funds. Thus, in order to retain its funding providers and dissuade investors from withdrawing, the Islamic bank would relinquish all or part of its profits for the benefit of the depositors;

- Equity investment risk: This risk arises from entering into a partnership for the purpose of undertaking or participating in a financing or general business activity as described in the contract (Helmy, 2012). Equity investment 
risk is obvious in Mudaraba (Note 4) and Musharaka (Note 5) contracts.

\section{Methodology and Data}

In Malaysia, some banks operate with both an Islamic window and a non-Islamic window (i.e. a conventional bank). Others are either purely conventional or Islamic (Qian \& Velayutham, 2017). For comparability purposes, this study only focuses on full-fledged Islamic banks.

Since the purpose of this paper is to examine in-practice Islamic banking risks, a qualitative approach is more appropriate. All data that was used in this study were obtained from the most recent reports available, namely the 2017 annual reports of five Islamic banks in Malaysia:

\section{$\checkmark$ Bank Islam Malaysia Berhad; \\ $\checkmark$ Bank Muamalat Malaysia Berhad; \\ $\checkmark \quad$ Kuwait Finance House Malaysia Berhad; \\ $\checkmark \quad$ Malaysia Building Society Berhad (MBSB) Bank Berhad; \\ $\checkmark$ Agrobank.}

This qualitative approach involved the use of direct observation. This technique requires paying systematic attention to information through note-taking that is designed to methodically record observations for later reproduction. This makes it possible to capture facts as they occur without interference, and allows for the collection of concrete data to guarantee the results' authenticity.

The variables that were observed were the risks mentioned in the annual reports of the five Islamic banks. These are the banking risks that have come to the reporting phase, which is the end of the management process.

The annual reports of the Islamic banks under study place the observed period in the reporting phase, which is part of the risk review phase. Nonetheless, it is necessary to briefly explain the content of the other phases of the process because the reporting concerns and recapitulates all of them. The risk management process consists of four phases (EID \& KAMAL, 2012):

- Identification phase: Risk exposures are identified (credit, market etc.) through risk mapping for example;

- Assessment phase: Risks are measured via qualitative and quantitative tools;

- Mitigation phase: Appropriate risk mitigation strategies are applied based on the bank's objectives;

- Review phase: Monitoring and reporting activities are provided for the risk management process.

After identifying the possible responses for each phase and codifying them, we arranged the variables in Figure 2 with checkboxes and collected the observations.

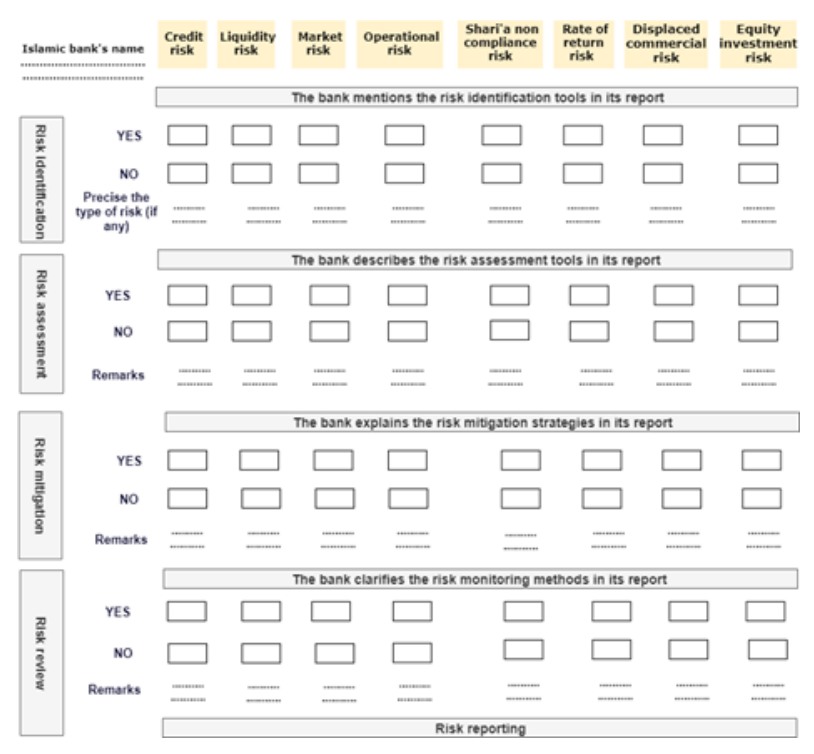

Figure 2. Observation grid used for the study

Source: Author 
The next section discusses the finding from the observations.

\section{Results and Discussion}

This study found that there are differences between theory and practice in terms of risks faced by full-fledged Islamic banks in Malaysia. These differences mainly pertain to classifying risk categories, to banks failing to report risks even though these risks are widely recognized in theory and in regard to a phase of the risk management process that suffers from deficiencies. Table 2 summarizes the results of this study.

Table 2. Study findings

\begin{tabular}{llllll}
\hline & $\begin{array}{c}\text { Bank Islam } \\
\text { Malaysia } \\
\text { Berhad }\end{array}$ & $\begin{array}{c}\text { Bank } \\
\text { Muamalat } \\
\text { Malaysia } \\
\text { Berhad }\end{array}$ & $\begin{array}{c}\text { Kuwait } \\
\text { Finance House } \\
\text { Malaysia } \\
\text { Berhad }\end{array}$ & $\begin{array}{c}\text { MBSB Bank } \\
\text { Berhad }\end{array}$ & $\begin{array}{c}\text { Agrobank } \\
\text { Credit risk }\end{array}$ \\
\hline Reported & Reported & Reported & Reported & Reported \\
\hline Liquidity risk & Reported & Reported & Reported & Reported & Reported \\
\hline Operational risk & Reported & Reported & Reported & Reported & Reported \\
\hline $\begin{array}{l}\text { Shari'a } \\
\text { non-compliance risk }\end{array}$ & Reported & Reported & Reported & Reported & Reported \\
\hline Rate of return risk & Reported & Unreported & Unreported & Unreported & Reported \\
\hline Equity investment risk & Reported & Reported & Unreported & Unreported & Unreported \\
\hline $\begin{array}{l}\text { Displaced commercial } \\
\text { risk }\end{array}$ & Unreported & Unreported & Unreported & Unreported & Unreported \\
\hline
\end{tabular}

Source: Author

The following section details the study's findings on the risks faced by the study sample, then discusses the probable explanations for these results.

The risks faced by Bank Islam Malaysia Berhad were acknowledged as follows (Bank Islam, 2017):

- $\quad$ All Islamic banking risks except for displaced commercial risk;

- The bank did not report all market risks and only reported rate of return risk, foreign exchange risk and equity investment risk (which the bank considers a market risk in contrast to what was discussed in theory);

- $\quad$ Other market risks were not mentioned;

- Operational risks were reported in terms of Shari'a non-compliance risk and IT risk, which suggests that the bank has its own method of classifying operational risks;

- $\quad$ All the other kinds of risks were reported normally.

The risks faced by Bank Muamalat Malaysia Berhad were reported as follows (Bank Muamalat Malaysia Berhad, 2017):

- This bank reported all Islamic banking risks except for displaced commercial risk and equity investment risk;

- Besides rate of return risk, the bank did not report any other market risks;

- Operational risks were reported in terms of Shari'a non-compliance risk, strategic risk and reputational risk. This classification, thus, did not fully follow the classification discussed in theory;

- $\quad$ All the other kinds of risks were reported normally.

The risks faced by Kuwait Finance House Malaysia, were reported as follows (Kuwait Finance House Malaysia Berhad, 2017):

- This bank reported on market risk, but did not provide any details on how it is managed. Therefore, the bank insufficiently addressed or completely ignored this issue. This bank also did not provide a classification of this risk; 
- $\quad$ The bank reported on operational risk, but did not classify it unlike the other banks in the sample. This bank mentioned Shari'a non-compliance risk;

- $\quad$ All the other common risks were reported normally.

The risks faced by MBSB Bank Berhad, were reported as follows (Malaysia Building Society Berhad, 2017):

- $\quad$ The bank reported on market risk, but like Kuwait Finance House Malaysia Berhad did not provide any details on how it is managed;

- $\quad$ The bank reported on operational risk, including Shari'a non-compliance risk, strategic risk and IT risk;

- $\quad$ All the other common risks were reported normally.

Finally, the risks faced by Agrobank were reported as follows (Agrobank, 2017):

- $\quad$ Market risk since the bank mentions managing rate of return risk but offers no details on the other market risks;

- Operational risk including Shari'a non-compliance risk. This bank did not classify this risk, unlike the other banks;

- $\quad$ All the other common risks were reported normally.

These results indicate that the risk reporting in the review phase that is supposed to summarize, all the stages of the risk management process does not in fact do so. Indeed, the Islamic banking risks that are common to the conventional banks are only mentioned, through a definition and the method generally used to quantify them. The findings are even more incomplete for specific risks because, since only some risks are mentioned in the bank reports; the reports only define the risks and provide little to no information about their management.

Again, all the reports did not give details about how those risks were identified. We can only assume that this is due to the absence of a risk-coding system that is based on the classified risks for Islamic banks. This system could have simplified the analysis of the related risks. The coding system proposes that each bank risk is assigned a code for extra reference for the risk. This would greatly assist risk reporting and monitoring within Islamic banks.

Moreover, all these banks did not report displaced commercial risk even though it constitutes a natural consequence of the rate of return risk, which is mentioned by the banks. In addition, it is clear that the banks have established their own operational risk classifications; several risks that have been recognized by the IFSB and the contemporary literature were not mentioned.

Another of this study's findings is that several of these banks, mentioned market risk but offered no details about how they manage it. This issue was also noted in the market risk factors that are shared by conventional banks and their Islamic counterparts (i.e. foreign exchange risk, equity price risk and commodity price risk). These factors were only partially mentioned by one of the sample banks.

Finally, according to the bank reports, it is clear that Islamic banks lacks suitable databases that can ease the adoption of appropriate risk measurement methods. This situation is unfavorable because of the increasing amount of business conducted by Islamic banks. These banks are operating in a competitive market and will be expected to keep pace with a satisfactory risk management system, which must include apt measurement of risks.

To recapitulate, the theory and practice regarding risk management in Islamic banking do not match for two main reasons:

First, the phases of the risk management process are not correctly carried out or are not carried out at all. This is especially the case in the first phase, namely risk identification, which should be as comprehensive as possible and include the sources of the risks or their causes, whether internal or external to the bank. The first phase is crucial because if a risk is missed during the identification phase, it is unlikely to be recognized in the other phases of the risk management process. The reports mention some measurement tools and the bank's risk mitigation strategy for the evaluation and mitigation phases, but these are only applicable to the risks that are common with conventional banks. The sample banks rarely or never reported information on the assessment and mitigation of risks specific to Islamic banks. Some risk mitigation procedures were reported for a few common risks;

Second, Islamic banking institutions presently face the challenge of designing an effective risk management framework due to the lack of standardization in financial reporting, the lack of appropriate quantitative measures and insufficient risk monitoring systems unlike conventional banks.

\section{Conclusion}

It should be recognized that risk management is a lively area, that necessitates frequent research because the global 
financial map changes continually (Agha \& Sabirzyanov, 2015). A suitable application of the framework would require multi-stakeholder collaboration of Islamic banks, regulators and supervisors to boost the enlargement of Islamic banks in theory and practice.

Generally, this research may be considered helpful for the Islamic banking industry as a better way for managing risks based on usual banking concepts. The risks that are faced by Islamic banks are more diverse and complex than their conventional counterparts, as are the innovations in the financial and banking products which the banks offer to the public.

This study seeks to determine if these risks differed in theory and practice and, if so, whether this variance was significant. The findings strongly suggest that there is indeed a significant difference between theory and practice in terms of the risks faced by Islamic banks.

The reasons for this difference are, however, difficult to explain. For example, why is displaced commercial risk never reported even though it is a natural consequence of the rate of return risk? Similarly, why does operational risk never have the same classification (except for Shari'a non-compliance risk) in these banks? Why is market risk mentioned in some bank reports when these banks provide no information about how this risk is managed?

These unanswered questions and the significant disparity between theory and practice only highlight the difficulties in risk management within Islamic banks. This study is simply one step along a long-term research agenda; more effort, particularly in relation to the risk management process (i.e. identifying, assessing, monitoring and reporting risks), needs to be taken to conduct a more detailed exploration of the policies and tools that can help Islamic banks overcome gaps in their risks handling process.

This purpose of overwhelming the gaps in the risk management process is sought after by Islamic banks, because the main goal of risk management is to maximize the bank's profit as defined by profitability and risk level (Khan \& Ahmed, 2001). The future of the Islamic banking industry significantly depends, on how these institutions can manage the numerous risks associated with their daily transactions.

\section{References}

Agha, S. E. U., \& Sabirzyanov, R. (2015). Risk Management in Islamic Finance: An Analysis from Objectives of Shari'ah Perspective. International Journal of Business, Economics and Law, 7(3), 2289-1552.

Agrobank. (2017). Annual Report.

Al-Suwailem, S. (2006). Hedging in Islamic finance, Vol. 10. Islamic Development Bank, Islamic Research and Training Institute.

Ariss, R. T. (2010). Competitive conditions in Islamic and conventional banking: A global perspective. Review of Financial Economics, 19(3), 101-108. https://doi.org/10.1016/j.rfe.2010.03.002

Bank Islam. (2017). Integrated Annual Report.

Bank Muamalat Malaysia Berhad. (2017). Annual Report.

Bouslama, G., \& Lahrichi, Y. (2017). Uncertainty and risk management from Islamic perspective. Research in International Business and Finance, 39, 718-726. https://doi.org/10.1016/j.ribaf.2015.11.018

De Coussergués, S., \& Bourdeaux, G. (2010). Gestion de la banque-6e éd.: Du diagnostic à la stratégie. Dunod.

Derbel, H., Bouraoui, T., \& Dammak, N. (2011). Can Islamic Finance Constitute A Solution to Crisis?. International Journal of Economics and Finance, 3(3), 75. https://doi.org/10.5539/ijef.v3n3p75

Eid, W., \& Kamal, A. (2012). Mapping the Risks and Risk Management Practices in Islamic Banking. PhD Thesis, Durham University.

Elgari, M. A. (2003). Credit risk in Islamic banking and finance. Islamic Economic Studies, 10(2), 1-25.

Guéranger, F. (2009). Finance islamique: une illustration de la finance éthique. Dunod.

Helmy, M. (2012). Risk management in Islamic banks. ESLSCA Business School.

Ismayil, S. I. (2012). The Principles of Islamic Finance, Its Challenges and Policy Suggestions for Azerbaijan. PhD Thesis, Eastern Mediterranean University (EMU).

Jouaber-Snoussi, K. (2012). III. Les risques dans la banque islamique. Repères, 47-68.

Kasri, R. (2007). Displaced commercial risk in Islamic banking: The case of Indonesia. Second Islamic economics conference "Comprehensive and balanced development among Islamic countries: Cooperation, opportunities 
and challenges". Kuala Lumpur.

Khan, T., \& Ahmed, H. (2001). Risk management: an analysis of issues in Islamic financial industry. Islamic Development Bank, Islamic Research and Training Institute.

Kuwait Finance House Malaysia Berhad. (2017). Annual Report.

Lahsasna, A. (2014). Shari'ah Non-Compliance Risk Management and Legal Documentation in Islamic Finance. John Wiley \& Sons. https://doi.org/10.1002/9781118809181

Malaysia Building Society Berhad. (2017). Annual Report.

Nwaolisa, E. F., \& Kasie, E. G. (2013). Islamic Banking in Nigeria: A Critical Appraisal of its Effect on the Nigerian Economy. Review of Public Administration and Management, 2(3). https://doi.org/10.12816/0001280

Qian, D. J., \& Velayutham, S. (2017). Conventional Banking and Islamic Banking: Do the Different Philosophies Lead to Different Financial Outcomes?. Journal of Wealth Management \& Financial Planning, 4, 3-14.

Rhanoui, S., \& Belkhoutout, K. (2018). Operational Risk in Both Conventional and Islamic Banking Perceptions: Differences and Similarities. European Scientific Journal, https://doi.org/10.19044/esj.2018.v14n13p110

Salem, R. A. (2013). Risk management for Islamic banks. Edinburgh University Press.

Yasin, F. (2014). Comparative study of risk management practices of Islamic versus conventional banks in Pakistan. IOSR Journal of Business and Management, 16(1), 79-82. https://doi.org/10.9790/487X-16127982

Zeineb, G. B., \& Mensi, S. (2014). Does the PLS Paradigm Spur the Islamic Banks Vs Conventional Banks Soundness: Case of the Global Financial Crisis. Journal of Economics and Development Studies, 2(3), 177-192. https://doi.org/10.15640/jeds.v2n3a13

\section{Notes}

Note 1. Political theorist, pedagogue and researcher (1878 to 1947).

Note 2. Company accredited by the British Accreditation Council for Independent Further and Higher Education as a provider of online, distance and mixed learning.

Note 3. Theologian and traditionalist Muslim jurisconsult of the 13th century and a member of the Hanbali school of jurisprudence.

Note 4. A contract between a capital provider and an entrepreneur, under which both parties agree to share the profits at a previously agreed-upon ratio or percentage and the losses are borne by the capital provider, except in cases of negligence or if the entrepreneur violates the terms of the contract.

Note 5. A contract in which the partners share both profits and losses. The profits are distributed among the partners according to a predetermined ratio, and the parties split the losses in proportion to each party's invested capital. 